\title{
Celiac sprue and abdominal lymphoma: Studies on the cell-mediated immune response of peripheral blood lymphocytes
}

P. Davis, MD, FrCP(C), H.J. Freeman, MD, FrCP(C), A.B.R. ThOMSON, MD, PhD, FrCP(C), FACP

\begin{abstract}
The development of primary abdominal lymphoma is a recognized complication of gluten-sensitive enteropathy (GSE). In five patients with GSE plus lymphoma, the distribution and function of peripheral blood lymphocytes were determined and compared with 13 patients with GSE without lymphoma and with 28 normal control subjects. The percentage of T cells was lower in patients with GSE and GSE with lymphoma than in controls, whereas patients with GSE plus lymphoma had a significantly increased number of peripheral blood B lymphocytes when compared with GSE patients or controls. There was no difference in K cell activity or lymphocyte responses to mitogens and antigens between controls, GSE or GSE plus lymphoma patients. Prospective studies are needed in patients with GSE to investigate whether this fall in peripheral blood $\mathrm{T}$ cells and rise in $\mathrm{B}$ lymphocytes is a marker of concurrent lymphoma. Can J Gastroenterol 1988; 2(1):12-14
\end{abstract}

Key Words: B cells, Celiac sprue, ConA, K cells, PHA, Primary abdominal lymphoma, $T$ cells, Varidase

Divisions of Gastroenterology and Rheumatology, Department of Medicine, University of Alberta, Edmonton, Alberta

Reprints: Dr A.B.R. Thomson, Nutrition and Metabolism Research Group, 519 Robert Newton Research Building, University of Alberta, Edmonton T6G $2 \mathrm{C} 2$

Received for publication October 26, 1987. Accepted January 18, 1988
CLUTEN-SENSITIVE ENTEROPATHY $\mathbf{J}(\mathrm{GSE})$ is a disease characterized by an intestinal reaction to gliadin. Although the exact mechanism of intestinal mucosal injury is unknown, there is growing evidence that it is immunologically mediated (1-3). It is characterized by the presence of increased numbers of lymphocytes in the lamina propria, increased local synthesis of antibody to gliadin and, sometimes, increased serum $\operatorname{Ig} \mathrm{A}$ and $\operatorname{IgM}$ levels. Both humoral and cell-mediated sensitization to gluten proteins have been reported in patients with celiac disease (4).

Impaired function of peripheral blood lymphocytes (5-7) and abnormalities of lymphocyte distribution (8) have been described in untreat- 
ed celiac disease. Although total lymphocyte counts are generally normal in untreated patients with celiac sprue, a reduction in the number of circulating thymus-dependent lymphocytes has been described $(9,10)$. However, $T$ cell numbers were normal after treatment with a gluten-free diet (9). Impaired lymphocyte responses to phytohemagglutinin (PHA) in untreated celiac disease may improve after treatment with a gluten-free diet (7).

$T$ cell depletion in the peripheral blood in the untreated patient with celiac disease might explain impaired blast transformation with nonspecific mitogens (5-7), and the association of malignancy and celiac disease $(11,12)$. However, not all studies have shown impaired response of $\mathrm{T}$ cells to mitogens and antigens in these patients (13). Intraepithelial lymphocytes bear the suppressor/cytotoxic $\mathrm{T}$ cell marker OKT8 (14), and the wheat protein $\propto$-gliadin has been shown to induce suppressor $\mathrm{T}$ cells in human peripheral blood from patients with celiac disease (15). Both cellular and hormonal sensitization to $\propto$-gliadin occur in this disorder $(16,17)$.

Malignant lymphomas may present with malabsorption and a jejunal mucosal lesion similar to that found in celiac patients (18). Malignancy may develop in untreated celiac patients (12). The mechanism of this association is not clearly understood but early resection of a localized malignant lesion may improve survival (19). Thus, detection of enteropathy-associated $\mathrm{T}$ cell lymphoma may have practical implications for management. These lymphomas were formerly called malignant histiocytosis of the intestine, but it is now considered that the malignant cell in these lymphomas is usually of $T$ cell origin (20-22).

Unlike patients with celiac disease, patients with enteropathy-associated T cell lymphoma do not have raised levels of $\propto$-gliadin antibody (23). As part of an ongoing study of cell-mediated immune responses in patients with bowel diseases the authors had the opportunity to study cell-mediated immune reponses in patients with GSE

TABLE 1

Numbers and function of lymphocytes

\begin{tabular}{|c|c|c|c|}
\hline & $\begin{array}{l}\text { Controls } \\
\text { (28) }\end{array}$ & $\begin{array}{l}\text { GSE } \\
(13)\end{array}$ & $\begin{array}{l}\text { GSE plus lymphoma } \\
\text { (5) }\end{array}$ \\
\hline E rosettes $(\%)$ & $50 \pm 5$ & $35 \pm 12^{\circ}$ & $38 \pm 12^{\circ}$ \\
\hline EA rosettes $(\%)$ & $25 \pm 5$ & $30 \pm 11$ & $29 \pm 9$ \\
\hline EAC rosettes $(\%)$ & $22 \pm 4$ & $24 \pm 2$ & $42 \pm 5^{\circ}$ \\
\hline K cell activity & $45 \pm 13$ & $49 \pm 26$ & $57 \pm 23$ \\
\hline PHA 50 & $3.04 \pm 1.21$ & $2.83 \pm 2.22$ & $2.71 \pm 1.34$ \\
\hline 100 & $3.29 \pm 1.35$ & $2.98 \pm 2.18$ & $2.85 \pm 1.49$ \\
\hline ConA & $2.46 \pm 1.18$ & $1.94 \pm 2.18$ & $2.75 \pm 1.43$ \\
\hline 100 & $2.23 \pm 1.57$ & $1.36 \pm 2.34$ & $2.84 \pm 1.54$ \\
\hline Varidase 50 & $1.18 \pm 1.13$ & $1.82 \pm 1.26$ & $1.30 \pm 1.11$ \\
\hline 100 & $1.10 \pm 1.12$ & $1.04 \pm 1.26$ & $1.39 \pm 1.98$ \\
\hline
\end{tabular}

$\cdot p<0.001$ (calculated for patient groups when compared to normal controls). Results expressed as mean \pm SEM. PHA Phytohemagglutinin

and in patients who had developed an associated lymphoma. The cell-mediated immune responsiveness of peripheral blood lymphocytes obtained from patients with celiac sprue or celiac sprue associated with abdominal lymphoma were examined and compared.

\section{PATIENTS AND METHODS}

The clinical details of the five patients with gluten-sensitive enteropathy plus lymphomas studied here have been reported (24). In each patient with lymphoma, the diagnosis of GSE was established on the basis of typical small bowel biopsies prior to treatment and a clinical, biochemical and histologic small bowel response to gluten restriction (24). Also, 13 patients, ranging in age from 17 to 58 years, with GSE but no clinical or radiological evidence of abdominal lymphoma were studied. All these patients were adhering to a gluten-free diet.

Distribution of peripheral blood lymphocytes were determined using $\mathrm{E}$ rosetting ( $\mathrm{T}$ cells), EAS rosetting (B cells) and EA rosetting ( $\mathrm{K}$ cells). In addition, $K$ cell activity and lymphocyte transformation responses to PHA, ConA and Varidase were studied using previously reported techniques (25). The results of the patients with GSE and the patients with GSE complicated with lymphoma were compared with 28 control subjects.

Statistical analysis of data was calculated using unpaired $t$ test.

\section{RESULTS}

The absolute numbers of peripheral blood lymphocytes were normal in all groups but the percentage of $T$ cells was significantly lower in patients with treated GSE without known lymphoma and patients with GSE plus lymphoma when compared to control subjects (Table 1). In the case of B cells, patients with GSE and lymphoma had a significantly increased number of peripheral blood B lymphocytes when compared to controls and patients with uncomplicated GSE ( $\mathrm{P}<0.001)$. The ratio of $T: B$ cells fell from 2.27 in normal subjects to 0.91 in GSE with lymphoma. The numbers of $\mathrm{K}$ cells were not significantly different between the three groups. There was no significant difference in $\mathrm{K}$ cell activity or peripheral blood lymphocyte responses to mitogens and antigens between patients with or without lymphoma and controls.

\section{DISCUSSION}

Decreased numbers of $\mathrm{T}$ cells have been described in untreated patients with celiac disease but these return to normal with gluten withdrawal (7). In the present study, treated patients with GSE claimed to be strictly adhering to the gluten-free diet, therefore, their reduced number of peripheral blood $\mathrm{T}$ cells was inexplicable. However, in agreement with previous studies, $T$ cell function was normal in patients with treated GSE (Table 1). This supports the previous suggestion that peripheral blood cell-mediated immune responses do not play a major role in the 
pathogenesis of GSE as assessed by peripheral blood lymphocyte transformation responses and $\mathrm{K}$ cell activity.

The present study demonstrated that the percentage rather than the number of peripheral blood T lymphocytes was lower in patients with GSE (with or without lymphoma) when compared to normal controls, and that patients with lymphoma had a significantly increased number of peripheral

\section{REFERENCES}

1. Marsh MN. The small intestine: mechanisms of local immunity and gluten sensitivity. Clin Sci 1981; 61:497-503.

2. Strober W. An immunological theory of gluten-sensitive enteropathy. In: McNicholl B, McCarthy CF, Fottrell PF, eds. Perspectives in Celiac Disease. Lancaster: MTP Press, 1978: 169.

3. Lam CWE, Thomson ABR. Update in Small Bowel Disease. Chicago: Year Book Medical Publishers, 1986: 63-97.

4. Cole SG, Kagnoff MF. Celiac disease. Ann Rev Nutr 1985; 5:241-66.

5. Blecher TE, Brzechwa-Ajdukiewicz A, McCorthy CF, et al. Serum immunoglobulins and lymphocyte transformation studies in coeliac disease. Gut $1969 ; 10: 57-62$.

6. Asquith P. Cell mediated immunity in coeliac disease. In: Hekkens WMJ, Pena AS, eds. Coeliac Disease. Second International Coeliac Symposium, Leiden. Stenfert Korese Leiden, 1974: 242-62.

7. Scott BB, Losowsky MS. Depressed cell-mediated immunity in coeliac disease. Gut 1976; 17:900-5.

8. Ferguson A, Murray D. Quantitation of intraepithelial lymphocytes in human jejunum. Gut 1971; 12: 988-94.

9. O'Donaghue DP, Lancaster-Smith M, Laviniere $P$, et al. T cell depletion in untreated adult coeliac disease. Gut blood B cells.

No single immunological process is likely to account for all the pathological changes and clinical features characteristic of the entire natural history of celiac sprue. Celiac disease nevertheless appears to represent a disturbance of normal protective mechanisms in the intestine, allowing sensitization to a dietary staple and the development of host damage. The relevance of this observation of a

$1976 ; 17: 328-31$.

10. Bullen AW, Losowsky MS. Lymphocyte subpopulations in adult coeliac disease. Gut 1978; 19:892-7.

11. Austad WI, Cornes JS, Gough KR, et al. Steatorrhea and malignant lymphoma. Am J Dig Dis 1967; 12:475-90

12. Harris DD, Cooke WT, Thompson H, et al. Malignancy in adult coeliac disease and idiopathic steatorrhea. Am J Med 1967; 42:899-912.

13. Strober W. The pathogenesis of gluten sensitive enteropathy. Ann Intern Med 1975; 83:242.

14. Selby WS, Janossy G, Bofill M, Jewell DP. Lymphocyte subpopulations in the human small intestine. The findings in normal mucosa and in the mucosa of patients with adult celiac disease. Clin Exp Immunol 1983; 52:219-28.

15. O'Farrelly C, Whelan CA, Feighery CF, Weir DG. Suppressor-cell activity in celiac disease induced by alphagliadin, a dietary antigen. Lancet 1984; ii:1305-7.

16. O'Farrelly C, Feighery C, Greally J, Wier DG. Cellular response to alpha gliadin in untreated celiac disease. Gut $1982 ; 23: 83-7$.

17. O'Farrelly C, Kelly J, Hekkens W, et al. Alpha gliadin antibody levels: a serological test for coeliac disease. Br Med J 1983; 286;2007-10. decreased percentage of $T$ cells and increased percentage of $\mathrm{B}$ cells to the development of lymphoma in GSE remains to be determined. Prospective studies are needed to investigate whether this rise in peripheral blood B cell populations is a marker of concurrent lymphoma, or if it is of use to distinguish between patients with uncomplicated celiac disease versus those with enteropathy-associated $T$ cell lymphoma.
18. Isaacson P, Wright DH. Intestinal lymphoma associated with malabsorp. tion. Lancet 1978; i:67-70.

19. Swinson CM, Coles EC, Salvin G, Booth CC. Coeliac disease and malignancy. Lancet 1983; i:111-5.

20. Isaacson PG, Spencer J, Connolly CE, et al. Malignant histiocytosis of the intestine: a T-cell lymphoma. Lancet 1985; i:688-91.

21. Loughran TP, Kadin ME, Deeg HJ T-cell intestinal lymphoma associated with celiac sprue. Ann Intern Med 1986; 104:44-7.

22. Salter DM, Krajewski AS, Dewer AE. Immunophenotype analysis of malignant histiocytosis of the intestine. J Clin Pathol 1986; 39:8-15.

23. O'Farrelly C, Feighery C, O'Brian DS, et al. Humoral response to wheat protein in patients with celiac disease and enteropathy-associated T cell lymphoma. Br Med J 1986; 293:908-10.

24. Freeman HJ, Weinstein WM, Shnitka TK, et al. Primary abdominal lymphoma. Presenting manifestation of celiac sprue, or complicating dermatitis herpetiformis. Am J Med 1977; 63:585-94.

25. Lyanga J, Davis P, Thomson ABR. In vitro testing of immunoresponsiveness in patients with inflammatory bowel disease. Clin Exp Immunol 1979; 37:120-5. 


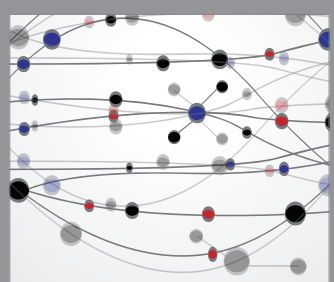

The Scientific World Journal
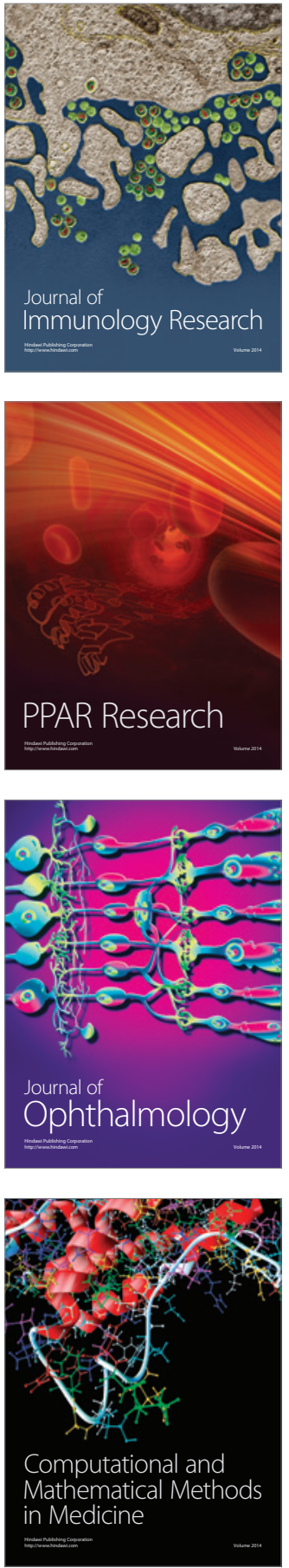

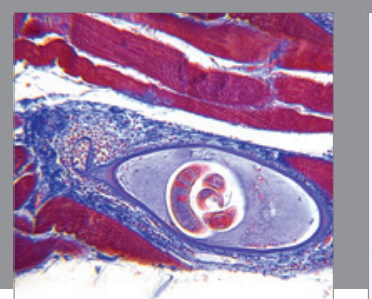

Gastroenterology Research and Practice



\section{Hindawi}

Submit your manuscripts at

http://www.hindawi.com

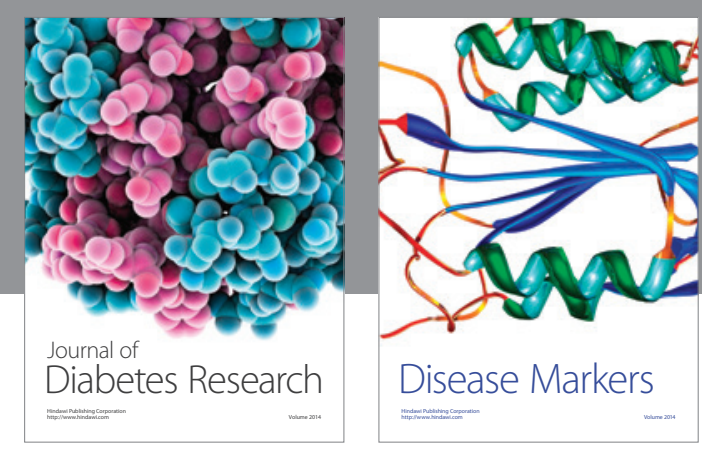

Disease Markers
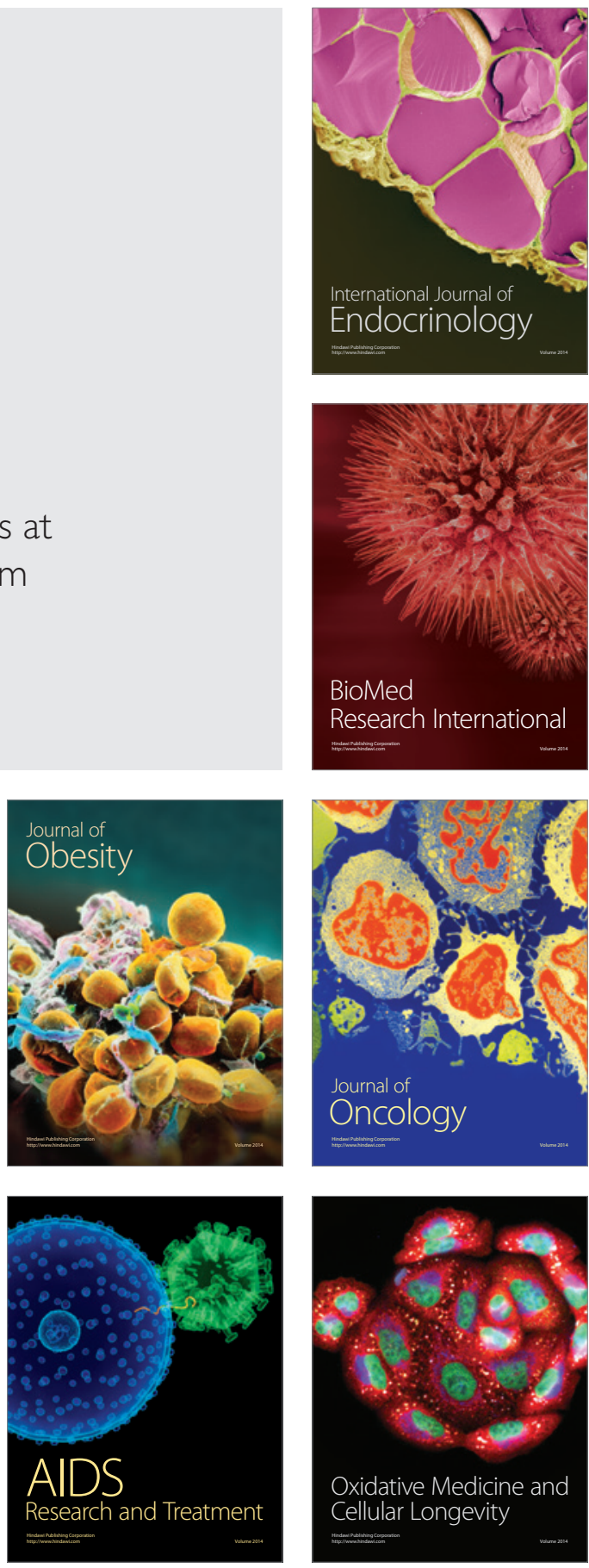